\title{
ASSESSMENT OF BARE NECESSITIES INDEX AND SUSTAINABLE LIVELIHOOD SECURITY INDEX OF SATARA DISTRICT MAHARASHTRA: A COMPARATIVE ANALYSIS
}

\author{
Dr. M. S. Deshmukh ${ }^{1}$, Dr. D. R. Nanaware ${ }^{2}$, Ajay D. Kumbhar ${ }^{3}$ \\ ${ }^{I}$ Professor, Department of Economics, Shivaji University, Vidyanagar, \\ Kolhapur Maharashtra- 416004. \\ ${ }^{2}$ Assistant Professor, Deccan Education Society, Pune, Chintamanrao College of Commerce, Sangli, \\ Maharashtra - 416415. \\ ${ }^{3}$ Research Scholar, Department of Economics, Shivaji University, Vidyanagar, \\ Kolhapur, Maharashtra- 416004.
}

Article DOI: https://doi.org/10.36713/epra7680

DOI No: $10.36713 /$ epra7680

The present paper examined the estimation and relationship between the Sustainable Livelihood Security Index (SLSI) and Bare Necessities Index (BNI) of rural area in Satara district. It covered four selected tehsils to analyze the relationship between the Sustainable Livelihood Security Index (SLSI) and the Bare Necessities Index (BNI). The exercise of estimation of SLSI based on three main dimensions i.e., social equity, economic efficiency, and ecological security along with its three sub-indicators of each dimension. Likewise. the estimation of BNI of Satara district is based on five main dimensions i.e., access to clean water, sanitation, housing, micro-environment, and other facilities also their 15 sub-indicators. This study observed that Mahabaleshwar tehsil has the lowest BNI and SLSI ranking whereas Koregoan tehsil was highest in BNI and second highest in SLSI. Phaltan tahsil has the highest SLSI whereas second highest in BNI as compared to selected tehsils in Satara district. The Bare Necessities Index (BNI) of Satara district was 0.531 whereas Sustainable Livelihood Security Index (SLSI) 0.566 during study period. Hence overall position of Satara district BNI and SLSI comes under medium category.

KEYWORDS: Sustainable Livelihood Security Index, Bare Necessities Index

\section{INTRODUCTION}

Satara district is one important district of western Maharashtra region of Maharashtra state. it is situated in western India with an area of $10,480 \mathrm{~km}^{2}$ which is about $3.4 \%$ of the Maharashtra state's total geographical area. It comprises elven tehsils with population size is $3,003,741$ which consist male and female population of $1,510,842$ and $1,492,899$ respectively. Nearly $81.1 \%$ of population is living in rural area having literacy rate of the $82.8 \%$. The population density is 287 per sq. km with sex ratio of this district 988. [4,5] Agricultural laborers constitute nearly $30.8 \%$ of the workforce, while $69.2 \%$ are cultivators. The cropping pattern of Satara district reveals that though cereals, pulses and oilseeds are grown, sugarcane cultivation has lion's share. It can thus be observed that agriculture is the leading activity in Satara district. [5]

The concept of Bare Necessities Index is firstly introduced in Economic Survey-2021, Govt. of India to examine the access of bare necessities to the people and inequalities. It is composite statistics of various bare necessities i.e., clean water, micro-environment sanitation, housing, and other facilities, etc. which needed for everyone to sustain their life. [6,7] The tehsil level Bare Necessities Index was estimated to assess the level of access of bare necessities and its inequalities in Satara district.

The concept of Sustainable Livelihood Security Index as livelihood choices which are ecologically secure, economically efficient and socially equitable. [2,10] Sustainable development can be described as 
development that meets the needs of the present without compromising the ability of future generations. [9] Franken Berger's point of view the Livelihood security can be defined as adequate and viable access to income and other resources to empower people to meet their basic wants. [3] Sustainable development is the supervisory principle for achieving human development goals, at the same time sustaining the ability of natural systems to provide the natural resources and ecosystem services upon which the economy and society depend. The desired outcome is a state of society in which living standard and resource use continue to meet human needs without undermining the integrity and stability of the natural system. The major objectives of this study are to estimate and measure the relationship between the Bare Necessities Index and Sustainable Livelihood Security Index of rural households in selected tehsils in Satara district.

\section{RESEARCH METHODOLOGY AND DATA BASE}

The present research paper is based on both primary and secondary data. However, it depends more on the primary data sources and field observations of the researchers. Bare Necessities Index (BNI) is an inclusive and newly introduced approach it focuses on the access to different basic/bare necessities to people which have each individual to sustain their life. It includes five main dimensions like clean water, sanitation, housing, micro-environment, and other facilities. [6,7] While the Sustainable Livelihood Security Index covers its three main dimensions' i.e., ecological security, economic efficiency, and social equity and its different subindicators. $[2,10,11]$ The possible proxy variables were used to estimate both the indices. The secondary data of various dimensions of bare necessities Index have been collected from the Census-2011, Government of India. The methodology to estimate the Bare Necessities Index have been adopted from economic survey-2021, Government of India. The sampling procedure reveals that based on cluster sampling method 4 out of 11 tehsils from Satara district were selected (which includes 3 border and 1 central block) covering 204 households from 24 identified villages through proportionate sampling method in Satara district.

$$
\left.n=\frac{N}{1+N(e)^{2}} \quad------(1) \quad 8\right]
$$

Where;

$$
\begin{aligned}
& \mathrm{n}=\text { Sample size required of Villages/Households } \\
& \mathrm{N}=\text { Number of Village /households for particular community } \\
& \mathrm{e}=\text { Error }
\end{aligned}
$$

\section{BNI \& SLSI framework and procedure}
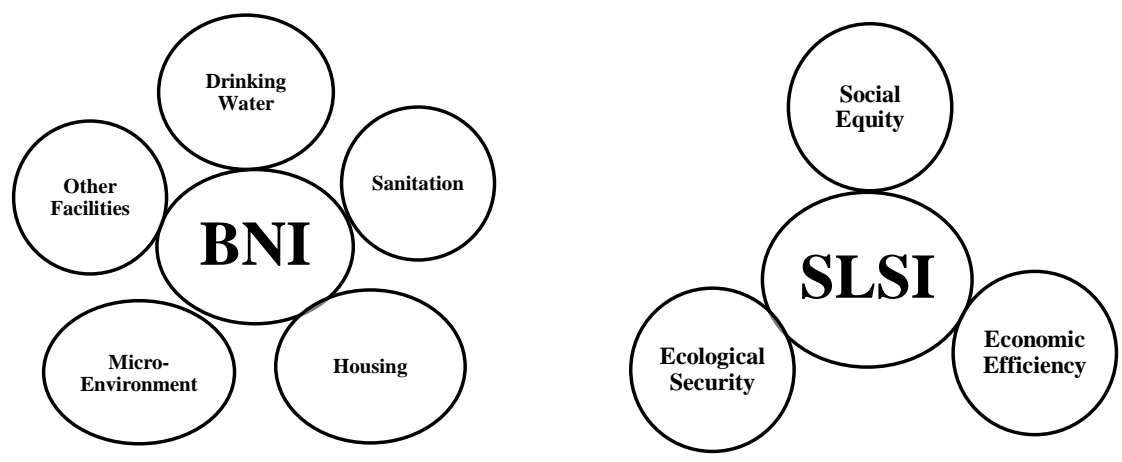


\section{Procedure to estimate BNI \& SLSI}

\begin{tabular}{|c|c|c|c|}
\hline \multicolumn{2}{|c|}{$\begin{array}{c}\text { Bare Necessities Index } \\
\text { (BNI) }\end{array}$} & \multicolumn{2}{|c|}{ Sustainable Livelihood Security Index (SLSI) } \\
\hline Domain & Indicators & Domain & Indicators \\
\hline Water (3) & $\begin{array}{l}\text { - Access to clean water (+ve) } \\
\text { - Location: Within Premises (+ve) } \\
\text { - Location: Away (-ve) }\end{array}$ & $\begin{array}{l}\text { Ecological } \\
\text { Security (4) }\end{array}$ & $\begin{array}{l}\text { - Area Under Crop (+ve) } \\
\text { - Total Population (-ve) } \\
\text { - Total Livestock (-ve) } \\
\text { - Cropping Intensity (+ve) }\end{array}$ \\
\hline Sanitation (3) & $\begin{array}{l}\text { - Bathing Facility(+ve) } \\
\text { - No-Bathing facility (-ve) } \\
\text { - Toilet Facility (+ve) }\end{array}$ & $\begin{array}{l}\text { Economic } \\
\text { Efficiency (5) }\end{array}$ & $\begin{array}{l}\text { - Food grain Production (+ve) } \\
\text { - Per Capita Income (+ve) } \\
\text { - Sugarcane Cultivation (+ve) } \\
\text { - Milk Production (+ve) } \\
\text { - Irrigated Area (+ve) }\end{array}$ \\
\hline Housing (3) & $\begin{array}{l}\text { - Kuccha House (-ve) } \\
\text { - Owned House (+ve) } \\
\text { - Pucca House (+ve) }\end{array}$ & $\begin{array}{l}\text { Social } \\
\text { Equity (5) }\end{array}$ & $\begin{array}{l}\text { - Female Literacy rate (+ve) } \\
\text { - Sex ratio (+ve) } \\
\text { - Heath Facility (+ve) } \\
\text { - Gender Gap in Literacy (-ve) } \\
\text { - BPL Population (-ve) }\end{array}$ \\
\hline $\begin{array}{l}\text { Micro- } \\
\text { Environment (3) }\end{array}$ & $\begin{array}{l}\text { - No drainage (-ve) } \\
\text { - Open drainage (-ve) } \\
\text { - Use of Dirt Fuel (-ve) }\end{array}$ & & \\
\hline $\begin{array}{l}\text { Other } \\
\text { Facilities (3) }\end{array}$ & $\begin{array}{l}\text { - Electricity access (+ve) } \\
\text { - Health Facilities (+ve) } \\
\text { - Use of LPG (+ve) }\end{array}$ & & \\
\hline
\end{tabular}

The Bare Necessities Index is a composite statistic of its different components includes 5 main domains and its 15 sub indicators includes 9 positive and 6 negatives, which described above table. Bare Necessities Index is computed by two steps, first step is aggregating the sub-indicators and calculate each sub-indicator's index. The second step is that, each dimension is aggregated using their scores calculated in step first for measuring Bare Necessities Index of the particular tehsils. The Bare Necessities Index is the arithmetic mean of its components, which is aggregated. The goalpost of each sub-indicator has fixed at minimum value is set 0 (Zero) and maximum values set is 100 (Hundred). The value of the index ranges between 0 and 1 , value closer to 0 indicates low access to bare necessities, and value closer to 1 reveals higher or better access to the bare necessities. Also, for better understanding there are three categories of BNI i.e., above 0.700 indicates 'High' level, 0.500 to 0.700 indicates 'Medium' level and below 0.500 indicates 'Very Low' level of access. The detailed exercise of constructing the Bare Necessities Index given below - [6,7]

$$
\begin{array}{r}
\text { Indicators Index }=\frac{(\text { Actual Value }- \text { Min.Value })}{(\text { Max.Value }- \text { Min.Value })}-------(1) \\
B N I=\frac{\left(I_{\text {Water }}+I_{\text {Sanitation }}+I_{\text {Housing }}+I_{\text {Micro-Environment }}+I_{\text {Other Facilities }}\right)}{1 / 5}--(2)
\end{array}
$$

Whereas;

$$
\begin{array}{rlrl}
I_{\text {Water }} & =\text { Drinking Water Index } & I_{\text {Micro-Environmer }}= & \text { Micro-Environment Index } \\
I_{\text {Sanitation }} & =\text { Sanitation Index } & I_{\text {Other Facilities }}=\text { Other Facilities Index } \\
I_{\text {Housing }} & =\text { Housing Index } & &
\end{array}
$$

The Sustainable Livelihood Security Index (SLSI) is a summary of various indicators and is computed by three main dimensions viz. Ecological Security Index, Economic Efficiency Index, and Social Equity Index and it's different around 13 sub-indicators which is grouped into positive and negative. The SLSI, which is a composite 
index, is calculated by taking the arithmetic mean of its component indices. The SLSI values vary between 0 and 1 and a value close to 0 indicates low level of sustainability and value close to 1 denotes a high level of sustainability. The SLSI construction exercise using 3 main domain and its 14 sub-indicators take equal weightage to all domain and indicators which explained above, detailed process of constructing SLSI given below- $[2,11]$

$$
S L S I_{i j k}=\frac{X_{i j k-} \operatorname{Min}_{x i j}}{\operatorname{Max}_{x i j-} \operatorname{Min}_{x i j}}----
$$

$$
\begin{aligned}
& \text { Where, } \\
& \qquad \begin{array}{l}
i=\text { variables }(1,2,3 \ldots i) \\
j=\text { components }(1,2,3, \ldots j) \\
k=\text { blocks }(1,2,3 \ldots k) \\
\qquad S L S I_{i j k} \sum_{i=1}^{I} S L S I_{i j k}------(4)
\end{array}
\end{aligned}
$$

\section{RESULTS AND DISCUSSIONS}

The present section of the research paper focuses on the different dimension of Substantiable Livelihood Security Index, moreover it also highlights the various indicators of Bare Necessities Index, which is key

\begin{tabular}{|c|c|c|c|c|}
\hline \multirow{2}{*}{ Sr. No. } & \multirow{2}{*}{ Tehsil/ } & \multirow{2}{*}{$\begin{array}{c}\text { Water Sources } \\
\text { Treated/Clean Water }\end{array}$} & \multicolumn{2}{|c|}{ Location of Source } \\
\hline & & & Within dwelling & Outside dwelling \\
\hline 1 & Mahabaleshwar & 30.4 & 45.7 & 9.3 \\
\hline 2 & Phaltan & 58.7 & 58.1 & 10.1 \\
\hline 3 & Karad & 68.7 & 67.7 & 7.6 \\
\hline \multirow[t]{2}{*}{4} & Koregoan & 74.5 & 71.9 & 5.7 \\
\hline & Satara District & 64.8 & 61.0 & 9.6 \\
\hline
\end{tabular}
measure of access of bare necessities to the people. Discussions and analysis of Substantiable Livelihood Security Index (SLSI) and Bare Necessities Index (BNI) of selected tehsils of Satara district

\section{Table - 01 \\ Selected Tehsils -wise Access of Clean Water Source with Location in Satara District}

Source: Census 2011/ Satara District

Table -01 shows the access of clean water sources with a location in the rural area of selected Tehsils of Satara district. Considering the clean water sources, it is observed that Koregaon has the highest, $74.5 \%$ followed by Karad, Phaltan, and Mahabaleshwar, 68.7\%, 58.7\%, and 30.4\% respectively. Satara total has about $64.8 \%$. Looking at within dwelling again Koregaon has highest $71.9 \%$ followed by Karad, Phaltan and Mahabaleshwar, $67.7 \%, 58.1 \%$, and $45.7 \%$ respectively, total Satara district within dwelling has $61.0 \%$. and outside dwelling, Phaltan has highest, $10.1 \%$ followed by Mahabaleshwar, Karad and Koregaon 9.3\%, 7.6\%, and 5.7\% respectively, total Satara district outside dwelling has only $9.6 \%$. 
Table - 02

Selected Tehsils -wise Access of Sanitation Facilities in Satara District

\begin{tabular}{clccc}
\hline \multirow{2}{*}{ Sr. No. } & \multicolumn{1}{c}{ Tehsil/ } & \multicolumn{3}{c}{ (Values in \%) } \\
\cline { 3 - 5 } & & Access of Bathing & No- bathing & Access of Toilet \\
\hline 1 & Mahabaleshwar & 95.5 & 4.4 & 91.2 \\
2 & Phaltan & 77.6 & 22.4 & 54.6 \\
3 & Karad & 92.1 & 7.9 & 68.0 \\
4 & Koregoan & 92.5 & 7.6 & 67.7 \\
\hline & Satara District & $\mathbf{8 8 . 7}$ & $\mathbf{1 1 . 4}$ & $\mathbf{7 0 . 1}$ \\
\hline
\end{tabular}

Source: Census 2011/ Satara District

Table - 02 illustrates the access to sanitation facilities in the rural area of selected Tehsils of Satara district. Looking at the access of bathing facilities, it is observed that Mahabaleshwar has the highest, $95.5 \%$ followed by Koregaon, Karad, and Phaltan, 92.5\%, 92.1\%, and 77.6\% respectively. Access to bathing facility Satara total has about $88.7 \%$. Considering about no-bathing facilities Phaltan has the highest $22.4 \%$ followed by Karad, Koregaon, and Mahabaleshwar, $7.9 \%, 7.6 \%$, and $4.4 \%$ respectively, total Satara district no-bathing facility has $11.4 \%$. Access to toilet facility, Mahabaleshwar has highest, $91.2 \%$ followed by Karad, Koregaon and Phaltan $68.0 \%, 67.7 \%$, and 54.6\% respectively, total Satara district has access of toilet facility only $70.1 \%$.

Table -03

Selected Tehsils -wise Access of Housing Facilities in Satara District

\begin{tabular}{|c|c|c|c|c|}
\hline \multirow[b]{3}{*}{$\begin{array}{c}\text { Sr. } \\
\text { No. }\end{array}$} & \multirow[b]{3}{*}{ Tehsil/ } & & & (Values in \\
\hline & & \multicolumn{3}{|c|}{ Housing Facilities } \\
\hline & & Kuccha dwelling & $\begin{array}{c}\text { Type of the } \\
\text { dwelling: Owned }\end{array}$ & Pucca dwelling \\
\hline 1 & Mahabaleshwar & 20.0 & 90.0 & 30.0 \\
\hline 2 & Phaltan & 57.1 & 92.9 & 3.6 \\
\hline 3 & Karad & 53.8 & 93.5 & 11.8 \\
\hline \multirow[t]{2}{*}{4} & Koregoan & 46.7 & 93.3 & 17.8 \\
\hline & Satara District & 51.5 & 93.1 & 11.8 \\
\hline
\end{tabular}

Source: Field Survey/ 2020-21

Table - 03 represents the access of housing facilities in the rural area of selected Tehsils of Satara district. Considering the Kuccha dwelling, it is observed that Phaltan has the highest, $57.1 \%$ followed by Karad, Koregaon, and Mahabaleshwar are 53.8\%, 46.7\%, and 20.0\% respectively. Satara total has kuccha dwelling about 51.5\%. Looking at owned house Karad has highest $93.5 \%$ followed by Koregaon, Phaltan and Mahabaleshwar is $93.3 \%, 92.9 \%$, and $90.0 \%$ respectively, total Satara district has owned house is about $93.1 \%$. While focusing on pukka dwelling, Mahabaleshwar has the highest, $30.0 \%$ followed by Koregaon, Karad, and Paltan $17.8 \%, 11.8 \%$, and $3 \%$ only respectively. Total Satara district pucca dwelling has only $11.8 \%$.

Table - 04

Selected Tehsils -wise Access of Micro-Environment Facilities in Satara District

\begin{tabular}{|c|c|c|c|c|}
\hline & \multirow[b]{3}{*}{ Tehsil/ } & & & (Values in \%) \\
\hline & & \multicolumn{3}{|c|}{ Micro-Environment Facilities } \\
\hline & & No drainage @ & Open drainage @ & $\begin{array}{c}\text { Use of Dirt Fuel } \\
\text { for Cooking } \$\end{array}$ \\
\hline 1 & Mahabaleshwar & 56.0 & 26.2 & 0.0 \\
\hline 2 & Phaltan & 70.8 & 20.5 & 1.8 \\
\hline 3 & Karad & 32.6 & 54.4 & 4.3 \\
\hline \multirow[t]{2}{*}{4} & Koregoan & 30.6 & 55.3 & 4.4 \\
\hline & Satara District & 46.9 & 41.8 & 8.2 \\
\hline
\end{tabular}

Sources: @ - Census 2011/Satara District, \$ - Field Survey/2020-21 
Table - 04 focuses on the access of micro-environment facilities in the rural area of selected Tehsils of Satara district. Considering the no drainage, it is observed that Phaltan has the highest, $70.8 \%$ followed by Mahabaleshwar, Karad, and Koregaon are 56.0\%, 32.6\%, and 30.6\% respectively. Satara total has lack of drainage facility is about $51.5 \%$. Looking at open drainage Koregaon has the highest $55.3 \%$ followed by Karad, Mahabaleshwar, and Phaltan are 54.4\%, 26.2\%, and 20.5\% respectively, total Satara district has open drainage is about $41.5 \%$. Focusing on the use of dirt fuel for cooking such as kerosene, firewood, etc. Koregaon has the highest $4.4 \%$. followed by Karad and Paltan $4.3 \%$ and $1.8 \%$ only respectively. Total Satara district use of dirt fuel for cooking has only $8.2 \%$.

Table - 05

Selected Tehsils -wise Access of Other Facilities in Satara District

\begin{tabular}{clccc} 
& & & \multicolumn{2}{c}{ (Values in \%) } \\
\cline { 3 - 5 } Sr. No. & Tehsil & Other Facilities & Access of Health \\
& & Access of electricity & $\begin{array}{c}\text { Use of LPG for } \\
\text { Cooking }\end{array}$ \\
\hline 1 & Mahabaleshwar & 100.0 & 20.0 & 100.0 \\
2 & Phaltan & 96.4 & 91.1 & 98.2 \\
3 & Karad & 94.6 & 19.4 & 95.7 \\
4 & Koregoan & 97.8 & 66.7 & 95.6 \\
\hline & Satara District & $\mathbf{9 6 . 1}$ & $\mathbf{4 9 . 5}$ & $\mathbf{9 1 . 8}$ \\
\hline
\end{tabular}

Source: Field Survey/ 2020-21

Table - 05 illustrates the access to electricity in the rural area of selected Tehsils of Satara district. Considering the access to electricity, it is found that Mahabaleshwar has the highest, 100.0\% followed by Koregaon, Phaltan, and Karad, 97.8\%, 96.4\%, and $94.6 \%$ respectively. Access to electricity in Satara from selected tehsil has about 96.1\%. Considering access to health facilities (PHC's), Phaltan has the highest 91.1\% followed by Koregaon, Mahabaleshwar, and Karad have, 66.7\%, 20.0\%, and 19.4\% respectively, total Satara district has access to health facilities (PHC's) about 11.4\%. Access to use of LPG gas for cooking, Mahabaleshwar has highest, $100.0 \%$ followed by Phaltan, Karad and Koregaon 980.2\%, 95.7\%, and 95.6\% respectively, total Satara district has access of health facilities (PHC's) about 91.8\%.

Table - 06

Selected Tehsils -wise Access of Clean Water Source with Location in Satara District

\begin{tabular}{|c|c|c|c|c|c|c|}
\hline \multirow[b]{2}{*}{$\begin{array}{l}\text { Sr. } \\
\text { No. }\end{array}$} & \multirow[b]{2}{*}{ Tehsil/ } & \multirow{2}{*}{$\begin{array}{c}\text { Water Sources } \\
\text { Treated/Clean } \\
\text { Water }\end{array}$} & \multicolumn{2}{|c|}{ Location of Source } & \multirow[b]{2}{*}{$\begin{array}{c}\text { Water Index } \\
\text { (WI) }\end{array}$} & \multirow[b]{2}{*}{ Rank } \\
\hline & & & $\begin{array}{c}\text { Within } \\
\text { dwelling }\end{array}$ & $\begin{array}{l}\text { Outside } \\
\text { dwelling }\end{array}$ & & \\
\hline 1 & Mahabaleshwar & 0.304 & 0.457 & 0.093 & 0.285 & 4 \\
\hline 2 & Phaltan & 0.587 & 0.581 & 0.101 & 0.423 & 3 \\
\hline 3 & Karad & 0.687 & 0.677 & 0.076 & 0.480 & 2 \\
\hline \multirow[t]{2}{*}{4} & Koregoan & 0.745 & 0.719 & 0.057 & 0.507 & 1 \\
\hline & Satara District & 0.648 & 0.610 & 0.096 & 0.451 & - \\
\hline
\end{tabular}

Source: Authors Calculation from Table 01

Fig. 01: Selected Tehsils -wise Water Index (WI) in Satara District

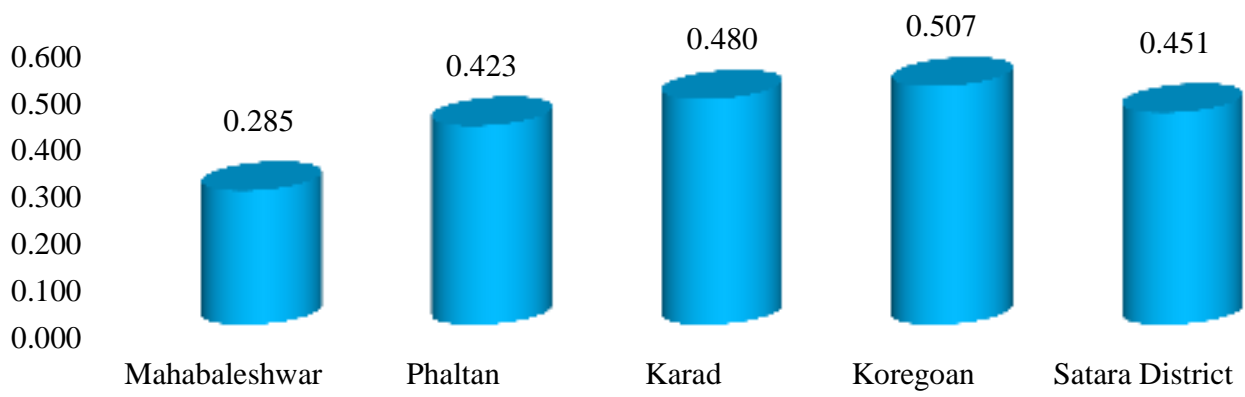

Table -06 \& Fig. 01 shows the selected tehsil-wise Water Index and its sub-indicator indices of Satara district. The high-water index indicates high access to water sources, the medium index has a medium, and the very low index has very low respectively. The Water Index of Koregaon has 0.507, which is the highest and stood at rank 
1, also indicates medium access of water sources to the people, followed by Karad, Phaltan and Mahabaleshwar i.e., $0.480,0.423$ and 0.285 respectively, it all have very low access of water sources. Considering the Satara district from selected tehsils, it has about 0.451 water index i.e., very low access to water sources in Satara district.

Table - 07

Selected Tehsils -wise Access of Sanitation Facilities in Satara District

\begin{tabular}{|c|c|c|c|c|c|c|}
\hline \multirow[b]{2}{*}{$\begin{array}{l}\text { Sr. } \\
\text { No. }\end{array}$} & \multirow[b]{2}{*}{ Tehsil/ } & \multicolumn{3}{|c|}{ Sanitation Facilities } & \multirow{2}{*}{$\begin{array}{l}\text { Sanitation } \\
\text { Facilities } \\
\text { Index (SFI) }\end{array}$} & \multirow[b]{2}{*}{ Rank } \\
\hline & & $\begin{array}{l}\text { Access of } \\
\text { Bathing }\end{array}$ & No- bathing & $\begin{array}{c}\text { Access of } \\
\text { Latrine }\end{array}$ & & \\
\hline 1 & Mahabaleshwar & 0.955 & 0.044 & 0.912 & 0.637 & 1 \\
\hline 2 & Phaltan & 0.776 & 0.224 & 0.546 & 0.515 & 4 \\
\hline 3 & Karad & 0.921 & 0.079 & 0.680 & 0.560 & 2 \\
\hline 4 & Koregoan & 0.925 & 0.076 & 0.677 & 0.559 & 3 \\
\hline & Satara District & 0.887 & 0.114 & 0.701 & 0.567 & - \\
\hline
\end{tabular}

Source: Authors Calculation from Table 02

Fig. 02: Selected Tehsils -wise Sanitation Index (SI) in Satara District

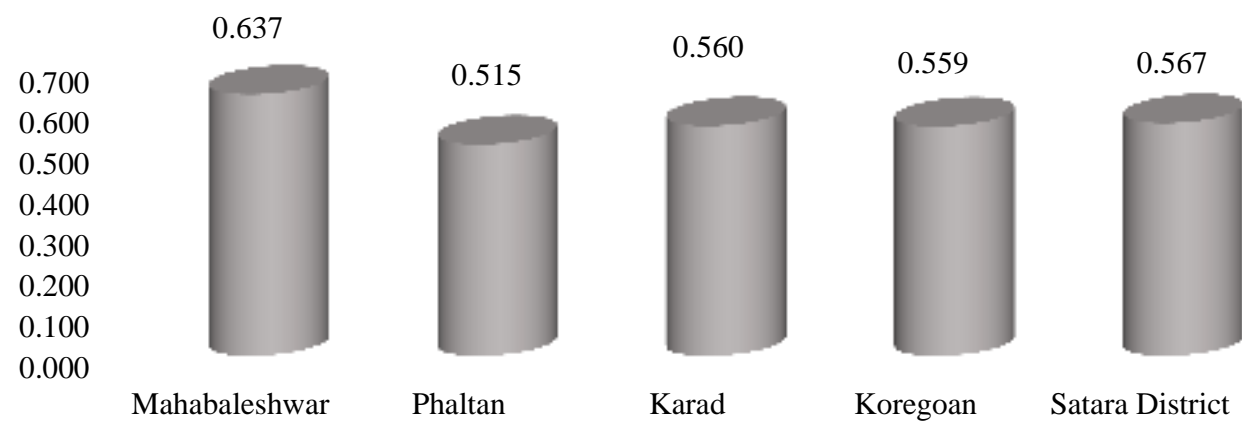

Table $-07 \&$ Fig. 02 focuses on the selected tehsil wise Sanitation Facilities Index and its sub-indicator indices of Satara district. The high Sanitation Facilities Index indicates high sanitation facilities, the medium index has a medium, and the very low index has very low. The Sanitation Facilities Index of Mahabaleshwar has 0.637, which is highest and stood at rank 1is, also indicates medium access of water sources to the people, followed by Karad, Koregaon and Phaltan i.e., 0.560, 0.559 and 0.515 respectively, it all have medium access of water sources. Considering as Satara district from selected tehsils, it has about 0.567 Sanitation Facilities Index i.e., medium access to sanitation facilities in Satara district.

Table -08

Selected Tehsils -wise Access of Housing Facilities in Satara District

\begin{tabular}{clccccc}
\hline \multirow{2}{*}{$\begin{array}{c}\text { Sr. } \\
\text { No. }\end{array}$} & \multicolumn{1}{c}{ Tehsil/ } & $\begin{array}{c}\text { Kuccha } \\
\text { dwelling }\end{array}$ & $\begin{array}{c}\text { Type of the } \\
\text { dwelling: Owned }\end{array}$ & $\begin{array}{c}\text { Pucca } \\
\text { dwelling }\end{array}$ & $\begin{array}{c}\text { Housing } \\
\text { Facilities Index } \\
\text { (HFI) }\end{array}$ & Rank \\
\cline { 3 - 6 } 1 & Mahabaleshwar & 0.200 & 0.900 & 0.300 & $\mathbf{0 . 4 6 7}$ & 4 \\
2 & Phaltan & 0.571 & 0.929 & 0.036 & $\mathbf{0 . 5 1 2}$ & 3 \\
3 & Karad & 0.538 & 0.935 & 0.118 & $\mathbf{0 . 5 3 0}$ & 1 \\
4 & Koregoan & 0.467 & 0.933 & 0.178 & $\mathbf{0 . 5 2 6}$ & 2 \\
\hline & Satara District & $\mathbf{0 . 5 1 5}$ & $\mathbf{0 . 9 3 1}$ & $\mathbf{0 . 1 1 8}$ & $\mathbf{0 . 5 2 1}$ & \\
\hline
\end{tabular}

Source: Authors Calculation from Table 03 


\section{Fig. 03: Selected Tehsils -wise Housing Index (HI) in Satara District}

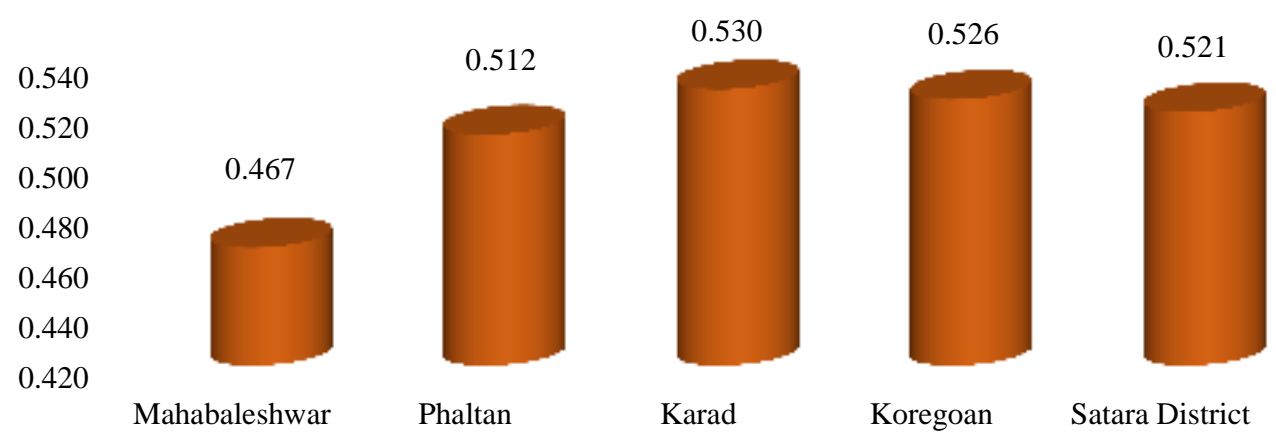

Table -08 \& Fig. 03 determines the selected tehsil wise Housing Facilities Index and its sub-indicator indices of Satara district. The high Housing Facilities Index indicates high Housing facilities, the medium index has a medium, and the very low index has very low. The Housing Facilities Index of Karad has 0.530, which is highest and stood at rank 1, also indicates medium access of Housing Facilities to the people, followed by Koregaon, Phaltan, and Mahabaleshwar i.e., 0.526, 0.512, and 0.467 respectively, it all have medium access of housing facilities, excluding Mahabaleshwar which has very low access. Considering as Satara district from selected tehsils, it has about 0.521 Sanitation Facilities Index i.e., medium access to sanitation facilities in Satara district.

Table - 09

Selected Tehsils -wise Access of Micro-Environment Facilities in Satara District

\begin{tabular}{clcccccc}
\hline \multirow{2}{*}{$\begin{array}{c}\text { Sr. } \\
\text { No. }\end{array}$} & \multirow{2}{*}{ Tehsil/ } & \multicolumn{2}{c}{ Micro-Environment Facilities } & Micro-Environment & Rank \\
\cline { 3 - 5 } & & $\begin{array}{c}\text { No } \\
\text { drainage }\end{array}$ & $\begin{array}{c}\text { Open } \\
\text { drainage }\end{array}$ & $\begin{array}{c}\text { Use of Dirt Fuel } \\
\text { for Cooking }\end{array}$ & $\begin{array}{c}\text { Facilities Index (MEFI) } \\
\text { Rank }\end{array}$ \\
\hline 1 & Mahabaleshwar & 0.560 & 0.262 & 0.000 & $\mathbf{0 . 2 7 4}$ & 4 \\
2 & Phaltan & 0.708 & 0.205 & 0.018 & $\mathbf{0 . 3 1 0}$ & 1 \\
3 & Karad & 0.326 & 0.544 & 0.043 & $\mathbf{0 . 3 0 4}$ & 2 \\
4 & Koregoan & 0.306 & 0.553 & 0.044 & $\mathbf{0 . 3 0 1}$ & 3 \\
\hline & Satara District & $\mathbf{0 . 4 6 9}$ & $\mathbf{0 . 4 1 8}$ & $\mathbf{0 . 0 8 2}$ & $\mathbf{0 . 3 2 3}$ & - \\
\hline
\end{tabular}

Source: Authors Calculation from Table 04

Fig. 04: Selected Tehsils -wise Micro-Environment Index (MEI) in Satara District

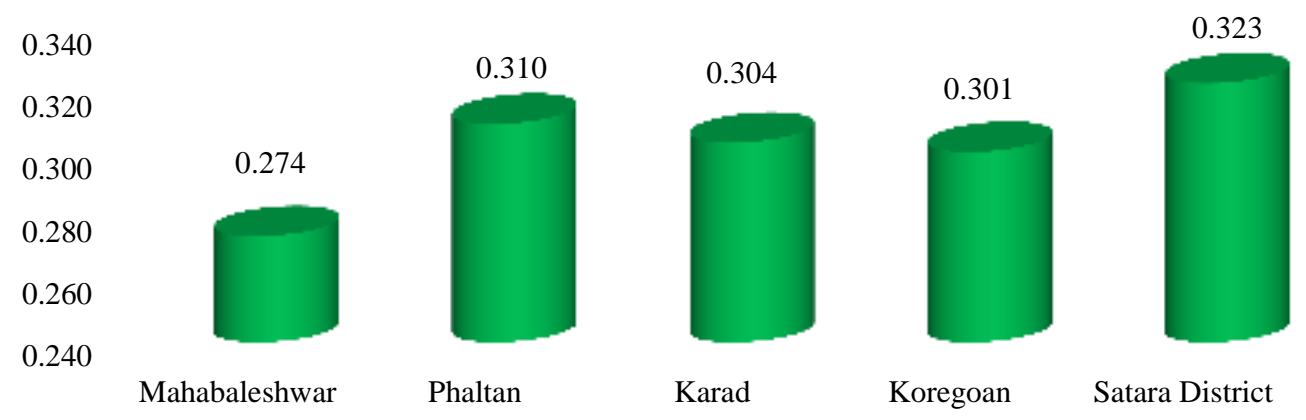

Table - 09 \& Fig. 04 shows the selected tehsil wise Micro-Environment Facilities Index and its sub-indicator indices of Satara district. The high Micro-Environment Facilities Index indicates high sanitation facilities, the medium index has a medium, and the very low index has very low. The Micro-Environment Facilities Index of Phaltan has 0.310 , which is highest and stood at rank $1^{\text {st }}$, also indicates very low access of Micro-Environment Facilities to the people, followed by Karad, Koregaon, and Mahabaleshwar i.e., 0.304, 0.301, and 0.274 respectively, it all have very low access of Micro-Environment Facilities. Seeing at total Satara district from selected tehsils, it has about 0.323 Sanitation Facilities Index i.e., very low access to sanitation facilities in Satara district. 
Table - 10

Selected Tehsils -wise Access of Other Facilities in Satara District

\begin{tabular}{|c|c|c|c|c|c|c|}
\hline \multirow[b]{2}{*}{$\begin{array}{l}\text { Sr. } \\
\text { No. }\end{array}$} & \multirow[b]{2}{*}{ Tehsil } & \multicolumn{3}{|c|}{ Other Facilities } & \multirow{2}{*}{$\begin{array}{c}\text { Other } \\
\text { Facilities } \\
\text { Index (OFI) }\end{array}$} & \multirow[b]{2}{*}{ Rank } \\
\hline & & $\begin{array}{l}\text { Access of } \\
\text { electricity }\end{array}$ & $\begin{array}{l}\text { Access of Health } \\
\text { Facilities (PHCs) }\end{array}$ & $\begin{array}{l}\text { Use of LPG } \\
\text { for Cooking }\end{array}$ & & \\
\hline 1 & Mahabaleshwar & 1.000 & 0.200 & 1.000 & 0.733 & 3 \\
\hline 2 & Phaltan & 0.964 & 0.911 & 0.982 & 0.952 & 1 \\
\hline 3 & Karad & 0.946 & 0.194 & 0.957 & 0.699 & 4 \\
\hline 4 & Koregoan & 0.978 & 0.667 & 0.956 & 0.867 & 2 \\
\hline & Satara District & 0.961 & 0.495 & 0.918 & 0.791 & - \\
\hline
\end{tabular}

Source: Authors Calculation from Table 05

Fig. 05: Selected Tehsils -wise Other Facilities Index (OFI) in Satara District

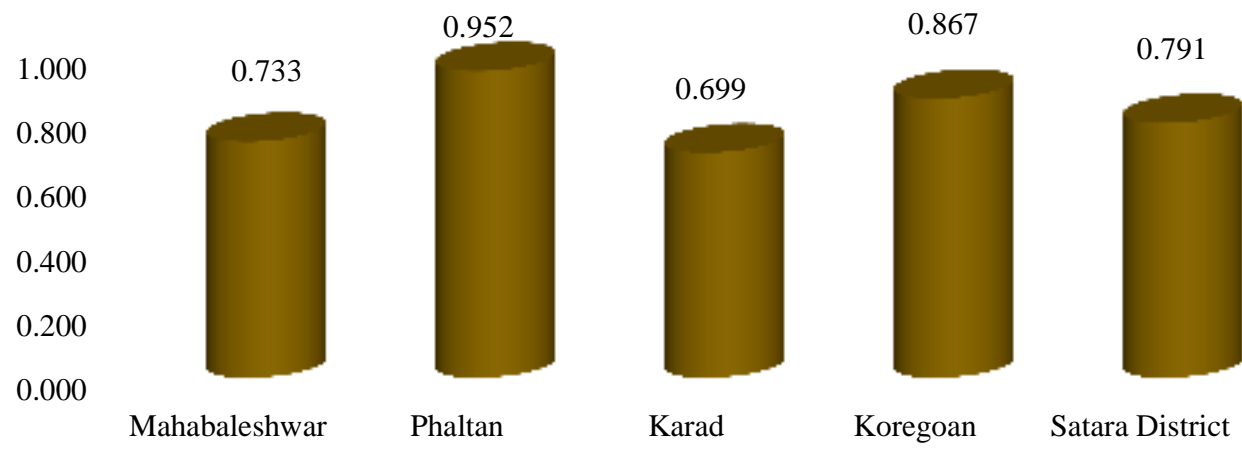

Table -10 \& Fig. 05 indicates the selected tehsil wise Other Facilities Index and its sub-indicator indices of Satara district. The high Other Facilities Index indicates high sanitation facilities, the medium index has a medium, and the very low index has very low. The Other Facilities Index of Phaltan has 0.952, which is the highest and stood at rank $1^{\text {st }}$, also indicates high access of other facilities to the people, followed by Koregaon, Mahabaleshwar and Karad i.e., 0.867, 0.733 and 0.699 respectively, it all have high access of other facilities. Karad is also very near to high access of other facilities. Looking at the Satara district from selected tehsils, it has about 0.791 Other Facilities Index i.e., high access to other facilities in Satara district.

Table - 11

Selected Tehsil-wise Ecological Security Indicators of Satara District

\begin{tabular}{|c|c|c|c|c|c|}
\hline \multicolumn{2}{|c|}{ Dimension } & \multicolumn{4}{|c|}{ Ecological Security Indicators } \\
\hline Criterio & & $\begin{array}{c}\text { Ecological } \\
\text { Balance }\end{array}$ & $\begin{array}{c}\text { Ecological } \\
\text { degradation }\end{array}$ & $\begin{array}{c}\text { Pressure on Natural } \\
\text { Resources }\end{array}$ & $\begin{array}{l}\text { Land Use, Soil } \\
\text { Fertility }\end{array}$ \\
\hline Sub-Ind & cators & $\begin{array}{c}\text { Area Under } \\
\text { Crop }\end{array}$ & $\begin{array}{c}\text { Total } \\
\text { Population }\end{array}$ & Total Livestock & $\begin{array}{l}\text { Cropping } \\
\text { Intensity }\end{array}$ \\
\hline Type & & + ve & -ve & -ve & $+v e$ \\
\hline Sr. No. & Tehsil/ Values & in Acre & in Number & in Number & in Number \\
\hline 1 & Mahabaleshwar & 23 & 41 & 16 & 2 \\
\hline 2 & Phalatan & 172 & 303 & 142 & 2 \\
\hline 3 & Karad & 277 & 493 & 269 & 2 \\
\hline 4 & Koregoan & 172 & 249 & 151 & 2 \\
\hline \multicolumn{2}{|c|}{ Satara District } & 644 & 1086 & 578 & 2 \\
\hline
\end{tabular}

Table - 11 indicates the Ecological Security Indicators in the rural area of selected Tehsils of Satara district. Considering the area under the crop of selected tehsils Satara district has 644 Acre, it is observed that Karad has the highest area, 277 Acre. Phaltan and Koregoan have equal areas i.e., 172 Acre and Mahabaleshwar has the lowest, 23 Acre. Looking at the population Satara district has 1086, Karad has the highest, 493, and Mahabaleshwar has the lowest, 4. It is identified that Satara district from selected tehsil has 578 total livestock. 
Karad has the highest livestock, 269 followed by Koregaon, Phaltan, and Mahabaleshwar, it has 151, 142, and 16 respectively. The cropping intensity of each bock is 2 times only.

Table - 12

Selected Tehsil-wise Economic Efficiency Indicators of Satara District

\begin{tabular}{|c|c|c|c|c|c|c|}
\hline \multicolumn{3}{|c|}{ Dimension } & \multicolumn{3}{|c|}{ Economic Efficiency Indicators } & \multirow[b]{2}{*}{$\begin{array}{c}\text { Assured } \\
\text { Water } \\
\text { Supply }\end{array}$} \\
\hline \multicolumn{2}{|c|}{ Criterion } & $\begin{array}{c}\text { Food } \\
\text { Security }\end{array}$ & $\begin{array}{l}\text { Agriculture } \\
\text { Output }\end{array}$ & Income of farms & $\begin{array}{c}\text { Source of } \\
\text { Rural } \\
\text { Likelihood } \\
\end{array}$ & \\
\hline \multicolumn{2}{|c|}{ Sub-Indicators } & $\begin{array}{l}\text { Food grain } \\
\text { Production } \\
\end{array}$ & $\begin{array}{l}\text { Per Capita } \\
\text { Income } \\
\end{array}$ & $\begin{array}{l}\text { Sugarcane } \\
\text { Cultivation } \\
\end{array}$ & $\begin{array}{c}\text { Milk } \\
\text { Production }\end{array}$ & $\begin{array}{c}\text { Irrigated } \\
\text { Area }\end{array}$ \\
\hline Type & & + ve & +ve & +ve & +ve & +ve \\
\hline Sr. No. & Tehsil/ Values & Quintal & In ₹ & in Acre & in Liter/day & in Acre \\
\hline 1 & Mahabaleshwar & 77 & 56978 & 3.9 & 55 & 15 \\
\hline 2 & Phalatan & 268 & 66816 & 29.2 & 1049 & 100 \\
\hline 3 & Karad & 421 & 62422 & 39 & 1215 & 161 \\
\hline 4 & Koregoan & 204 & 76144 & 25.5 & 542 & 83 \\
\hline \multicolumn{2}{|c|}{ Satara District } & 970 & 66589 & 97.6 & 2861 & 359 \\
\hline
\end{tabular}

Source: Field Survey/2020-21

Table - 12 shows the Economic Efficiency Indicators in the rural area of selected Tehsils of Satara district. Looking at the food grain production in the selected tehsil of Satara district has 970 Quintal, it is observed that Karad has the highest production, 421 Quintal. Followed by Phaltan, Koregaon, and Mahabaleshwar, it all has 268, 204, and 77 respectively. Considering per capita income in the selected tehsil of Satara district has 66589/. Looking at the Sugarcane Cultivation it has total of 97.6 Acre agricultural land. Phaltan has the highest, 29.2 Acre and Mahabaleshwar has the lowest land, 3.9 Acre. Satara district has milk production of about 2861 lit/day. Mahabaleshwar has the lowest, 55 lit/day and Karad has the highest, 1215 lit/day. Considering the total irrigated area of Satara district from selected tehsil has, 359 Acre. Mahabaleshwar has the lowest, 15 Acre and Karad has highest, 161 acres.

Table - 13

Selected Tehsil-wise Social Equity Indicators of Satara District

\begin{tabular}{|c|c|c|c|c|c|c|}
\hline \multicolumn{3}{|c|}{ Dimension } & \multicolumn{3}{|c|}{ Social Equity Indicators } & \multirow[b]{2}{*}{$\begin{array}{c}\text { Living } \\
\text { Standard }\end{array}$} \\
\hline \multicolumn{2}{|c|}{ Criterion } & $\begin{array}{c}\text { Educational } \\
\text { Status }\end{array}$ & $\begin{array}{l}\text { Gender } \\
\text { Equity }\end{array}$ & Health Services & $\begin{array}{l}\text { Social } \\
\text { Equity }\end{array}$ & \\
\hline \multicolumn{2}{|c|}{ Sub-Indicators } & $\begin{array}{c}\text { Female } \\
\text { Literacy rate }\end{array}$ & Sex ratio & Heath Facility & $\begin{array}{l}\text { Gender Gap } \\
\text { in Literacy }\end{array}$ & $\begin{array}{c}\text { BPL } \\
\text { Population }\end{array}$ \\
\hline \multicolumn{2}{|l|}{ Type } & + ve & +ve & +ve & -ve & -ve \\
\hline Sr. No. & Tehsil/ Values & in $\%$ & Numbers & in $\%$ & in $\%$ & in $\%$ \\
\hline 1 & Mahabaleshwar & 70.6 & 708 & 20.0 & 29.4 & 20.0 \\
\hline 2 & Phalatan & 87.6 & 835 & 91.1 & -0.4 & 16.1 \\
\hline 3 & Karad & 80.4 & 802 & 19.4 & 9.3 & 19.4 \\
\hline 4 & Koregoan & 84.2 & 844 & 66.7 & 6.2 & 22.2 \\
\hline \multicolumn{2}{|c|}{ Satara District } & 80.7 & 797 & 49.3 & 11.1 & 19.4 \\
\hline
\end{tabular}

Source: Field Survey/2020-21

Table - 13 focuses on the Social Equity Indicators in the rural area of selected Tehsils of Satara district. Considering the female literacy rate in the selected tehsil of Satara district, it has $80.7 \%$. It is observed that Phaltan has the highest female literacy rate, $87.6 \%$. Followed by Koregaon, Karad, and Mahabaleshwar, it all has $84.2 \%, 80.4 \%$. and $70.6 \%$. respectively. Looking at sex ratio in the selected tehsil of Satara district has 797. Koregaon has the highest sex ratio, it has 844 followed by Phaltan, Karad, and Mahabaleshwar, it all has 835 , 802, and 708 respectively. Considering the health facilities, in the selected tehsil of Satara district, it has 49.3\%, it is observed that Phaltan has the highest health facilities, 91.1\%. Followed by Koregaon, Mahabaleshwar, and Karad, it all has $66.7 \%, 20.0 \%$. and $19.4 \%$. respectively. 
Looking at the gender gap in literacy in the selected tehsil of Satara district, it has $11.1 \%$, it is observed that Mahabaleshwar has the highest gender gap in literacy, 29.4\%. Followed by Karad, Koregaon, and Phaltan, it all has $9.3 \%, 6.2 \%$. and $-0.4 \%$ respectively. Considering the BPL population in the selected tehsil of Satara district, it has $19.4 \%$, it is observed that Koregaon has the highest BPL population, 22.2\%. Followed by Mahabaleshwar, Karad, and Phaltan, it all has 20.0\%, 19.4\%. and 16.1\% respectively.

Table - 14

Selected Tehsil-wise Ecological Security Index \& Its Components Indices of Satara District

\begin{tabular}{|c|c|c|c|c|c|c|}
\hline \multicolumn{2}{|c|}{ Dimension } & \multicolumn{4}{|c|}{ Ecological Security Index } & \multirow{5}{*}{$\begin{array}{c}\text { Ecological } \\
\text { Security } \\
\text { Index } \\
\text { (ESI) }\end{array}$} \\
\hline \multicolumn{2}{|c|}{ Criterion } & $\begin{array}{c}\text { Ecological } \\
\text { Balance }\end{array}$ & $\begin{array}{c}\text { Ecological } \\
\text { degradation }\end{array}$ & $\begin{array}{c}\text { Pressure on } \\
\text { Natural } \\
\text { Resources } \\
\end{array}$ & $\begin{array}{l}\text { Land Use, } \\
\text { Soil Fertility }\end{array}$ & \\
\hline \multicolumn{2}{|c|}{ Sub-Indicators } & $\begin{array}{l}\text { Area Under } \\
\text { Crop }\end{array}$ & $\begin{array}{c}\text { Total } \\
\text { Population } \\
\end{array}$ & Total Livestock & $\begin{array}{l}\text { Cropping } \\
\text { Intensity }\end{array}$ & \\
\hline \multicolumn{2}{|l|}{ Type } & +ve & -ve & -ve & + ve & \\
\hline Sr. No. & Tehsil/ Values & in Acre & in Number & in Number & in Number & \\
\hline 1 & Mahabaleshwar & 0.000 & 1.000 & 1.000 & 1.000 & 0.750 \\
\hline 2 & Phaltan & 0.587 & 0.420 & 0.502 & 1.000 & 0.627 \\
\hline 3 & Karad & 1.000 & 0.000 & 0.000 & 1.000 & 0.500 \\
\hline 4 & Koregoan & 0.587 & 0.540 & 0.466 & 1.000 & 0.648 \\
\hline $\mathbf{S a}$ & ara District & 0.543 & 0.490 & 0.492 & 1.000 & 0.631 \\
\hline
\end{tabular}

Source: Authors Calculation from table - 11

Fig. 06: Selected Tehsil-wise Ecological Security Index (ESI) of Satara District

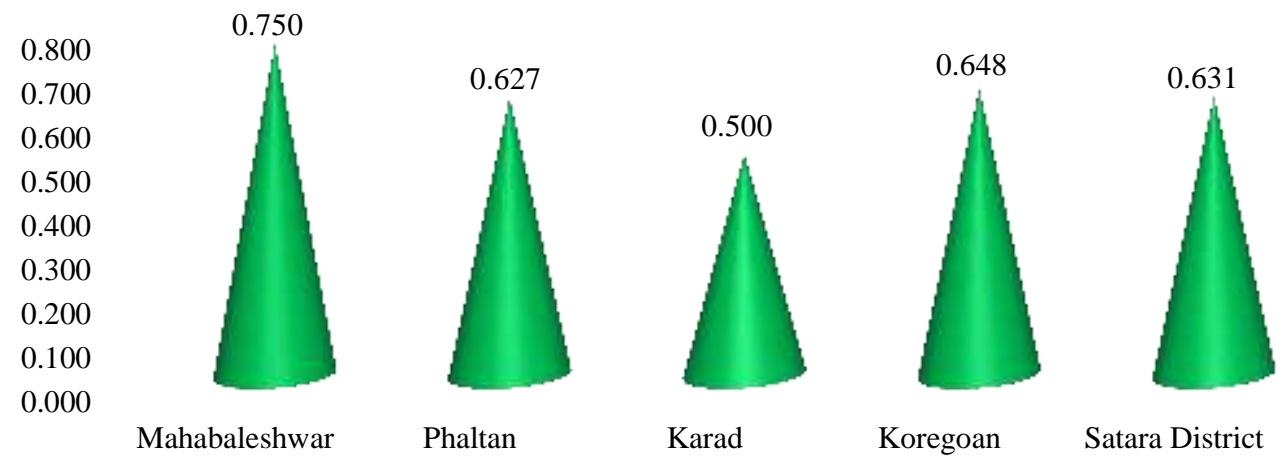

Table -14 \& Fig. 06 indicates the evaluation of the Ecological Security Index (ESI) and its different indices in selected tehsils in the Satara district. Ecological Security Index is one of important domain of Sustainable Livelihood Security Index, it has been calculated thought its four indicators which categorized under positive and negative. The ESI of Mahabaleshwar has 0.750 which is the highest and also high development category. While the Karad has 0.500 which is the lowest and it comes under the medium development category as compared to selected tehsils. Looking at the overall progress of Ecological Security Index of Satara district has calculated at 0.631, which under the medium development category. Shortly, based on the estimated Ecological Security Index of selected tehsils along with Satara district, except Mahabaleshwar, all these tehsils with Satara district have existed under medium or low development during the study period. 
Table - 15

Selected Tehsil-wise Economic Efficiency Index \& Its Components Indices of Satara District

\begin{tabular}{|c|c|c|c|c|c|c|c|}
\hline \multicolumn{2}{|c|}{ Dimension } & \multicolumn{5}{|c|}{ Economic Efficiency Index } & \multirow{5}{*}{$\begin{array}{l}\text { Economic } \\
\text { Efficiency } \\
\text { Index } \\
\text { (EEI) }\end{array}$} \\
\hline \multicolumn{2}{|l|}{ Criterion } & $\begin{array}{c}\text { Food } \\
\text { Security }\end{array}$ & $\begin{array}{l}\text { Agricultu } \\
\text { re Output }\end{array}$ & $\begin{array}{l}\text { Income of } \\
\text { farms }\end{array}$ & $\begin{array}{c}\text { Source of } \\
\text { Rural } \\
\text { Likelihood }\end{array}$ & $\begin{array}{l}\text { Assured } \\
\text { Water } \\
\text { Supply }\end{array}$ & \\
\hline \multicolumn{2}{|c|}{ Sub-Indicators } & $\begin{array}{l}\text { Food grain } \\
\text { Production }\end{array}$ & $\begin{array}{l}\text { Per Capita } \\
\text { Income }\end{array}$ & $\begin{array}{l}\text { Sugarcane } \\
\text { Cultivation }\end{array}$ & $\begin{array}{c}\text { Milk } \\
\text { Production }\end{array}$ & $\begin{array}{c}\text { Irrigated } \\
\text { Area }\end{array}$ & \\
\hline Type & & + ve & + ve & + ve & + ve & + ve & \\
\hline Sr. No. & Tehsil/ Values & Quintal & In ₹ & in Acre & in Liter/day & in Acre & \\
\hline 1 & Mahabaleshwar & 0.000 & 0.000 & 0.000 & 0.000 & 0.000 & 0.000 \\
\hline 2 & Phaltan & 0.555 & 0.513 & 0.721 & 0.857 & 0.582 & 0.646 \\
\hline 3 & Karad & 1.000 & 0.284 & 1.000 & 1.000 & 1.000 & 0.857 \\
\hline 4 & Koregoan & 0.369 & 1.000 & 0.615 & 0.420 & 0.466 & 0.574 \\
\hline \multicolumn{2}{|c|}{ Satara District } & 0.481 & 0.449 & 0.584 & 0.569 & 0.512 & 0.519 \\
\hline
\end{tabular}

Source: Authors Calculation from table - 12

Fig. 07: Selected Tehsil-wise Economic Efficiency Index (EFI) of Satara District

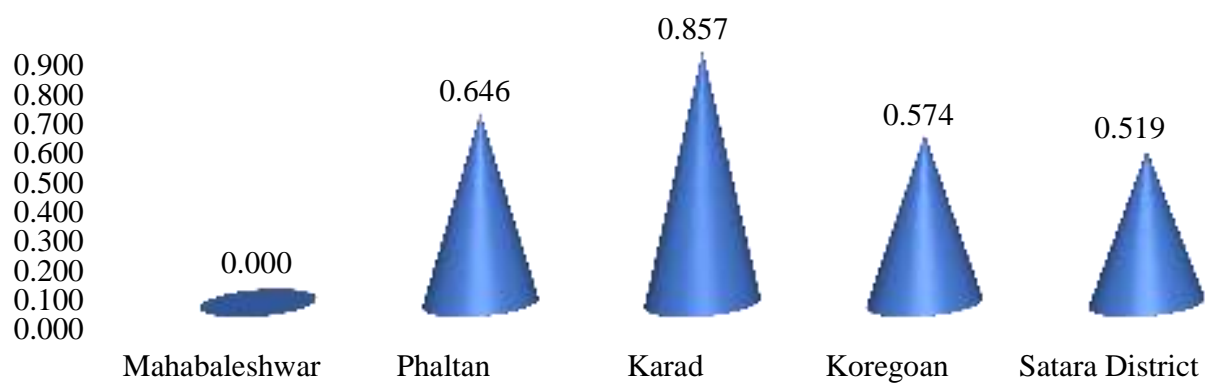

Table -15 \& Fig. 07 reveals the evaluation of the Economic Efficiency Index (EEI) and its different indices of selected tehsils in the Satara district. Economic Efficiency Index is the second vital domain of the Sustainable Livelihood Security Index, it has been calculated through its five basic indicators which all treated as positive. The Economic Efficiency Index of Karad has noted 0.857 which is the highest and also under the very high development category. While the Mahabaleshwar has calculated 0.000 which is the lowest and it comes under the very low development category as compared to selected tehsils. Considering as the overall improvement of Economic Efficiency Index of Satara district has counted at 0.519, which under the medium development category and also lower except Mahabaleshwar than other selected tehsils. Shortly, the estimated Economic Efficiency Index of selected tehsils with Satara district reveals, Karad tehsils did well-performed while Mahabaleshwar performed very poorly in Economic Efficiency Index during the study period.

Table - 16

Selected Tehsil-wise Social Equity Index \& Its Components Indices of Satara District

\begin{tabular}{|c|c|c|c|c|c|c|c|}
\hline \multicolumn{2}{|c|}{ Dimension } & \multicolumn{5}{|c|}{ Social Equity Index } & \multirow{4}{*}{$\begin{array}{l}\text { Social } \\
\text { Equity } \\
\text { Index } \\
\text { (SEI) }\end{array}$} \\
\hline \multicolumn{2}{|c|}{ Criterion } & $\begin{array}{c}\text { Educational } \\
\text { Status }\end{array}$ & $\begin{array}{l}\text { Gender } \\
\text { Equity }\end{array}$ & $\begin{array}{c}\text { Health } \\
\text { Services }\end{array}$ & $\begin{array}{l}\text { Social } \\
\text { Equity }\end{array}$ & $\begin{array}{c}\text { Living } \\
\text { Standard }\end{array}$ & \\
\hline \multicolumn{2}{|c|}{ Sub-Indicators } & $\begin{array}{c}\text { Female } \\
\text { Literacy rate }\end{array}$ & Sex ratio & $\begin{array}{c}\text { Heath } \\
\text { Facility }\end{array}$ & $\begin{array}{l}\text { Gender Gap } \\
\text { in Literacy }\end{array}$ & $\begin{array}{c}\text { BPL } \\
\text { Population }\end{array}$ & \\
\hline \multicolumn{2}{|l|}{ Type } & $+v e$ & +ve & +ve & -ve & -ve & \\
\hline Sr. No. & Tehsil/ Values & in $\%$ & Numbers & in $\%$ & in $\%$ & in $\%$ & \\
\hline 1 & Mahabaleshwar & 0.000 & 0.000 & 0.008 & 0.000 & 0.361 & 0.074 \\
\hline 2 & Phaltan & 1.000 & 0.934 & 1.000 & 1.000 & 1.000 & 0.987 \\
\hline 3 & Karad & 0.576 & 0.691 & 0.000 & 0.674 & 0.459 & 0.480 \\
\hline 4 & Koregoan & 0.800 & 1.000 & 0.660 & 0.779 & 0.000 & 0.648 \\
\hline \multicolumn{2}{|c|}{ Satara District } & 0.594 & 0.656 & 0.417 & 0.613 & 0.455 & 0.547 \\
\hline
\end{tabular}

Source: Authors Calculation from table - 13 
Fig. 08: Selected Tehsil-wise Economic Efficiency Index (EFI) of Satara District

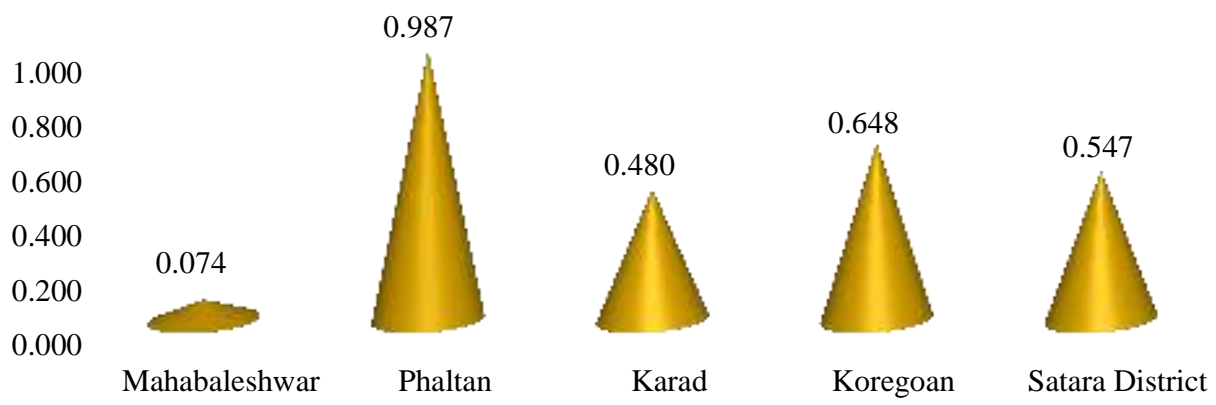

Table -16 \& Fig. 08 reveals the estimation of the Social Equity Index (SEI) and its diverse indices of selected five tehsils in the Satara district. Social Equity Index is a third essential dimension for measuring the Sustainable Livelihood Security Index of selected tehsils, it has been calculated by its five basic indicators which grouped into three positive and two negatives. Observing selected tehsil-wise Social Equity Index, Phaltan has been noted 0.987 which is the highest also under the very high development category. While the Mahabaleshwar has 0.074 which is stood lowest and it comes under the very low development category as compared to selected tehsils. Looking at the overall progress of the Social Equity Index of Satara district has reported 0.547, which under the medium development category and also lower except Mahabaleshwar than other selected tehsils. Shortly, the evaluated Social Equity Index of selected tehsils with Satara district exposes that Phaltan tehsils did well-performed, but Mahabaleshwar and Karad, performed very poorly in Social Equity Index during the study period.

Table - 17

Selected Tehsils -wise Bare Necessities Index (BNI) and Sustainable Livelihood Security Index (SLSI) in Rural Area of Satara District

\begin{tabular}{|c|c|c|c|c|c|c|}
\hline $\begin{array}{l}\text { Sr. } \\
\text { No. }\end{array}$ & Tehsil & BNI & Rank & SLSI & Rank & $\begin{array}{c}\text { Gap } \\
\text { (SLSI - BNI) }\end{array}$ \\
\hline 1 & Mahabaleshwar & 0.479 & 4 & 0.275 & 4 & -0.204 \\
\hline 2 & Phaltan & 0.543 & 2 & 0.753 & 1 & 0.210 \\
\hline 3 & Karad & 0.515 & 3 & 0.612 & 3 & 0.097 \\
\hline \multirow[t]{2}{*}{4} & Koregoan & 0.552 & 1 & 0.623 & 2 & 0.071 \\
\hline & Satara District & 0.531 & - & 0.566 & - & 0.035 \\
\hline
\end{tabular}

Source: Authors Calculation [BNI from Table 06 to 10, SLSI from table 14 to 16]

Fig. 09: Selected Tehsils -wise Bare Necessities Index (BNI) and Sustainable Livelihood Security Index (SLSI) in Rural Area of Satara District

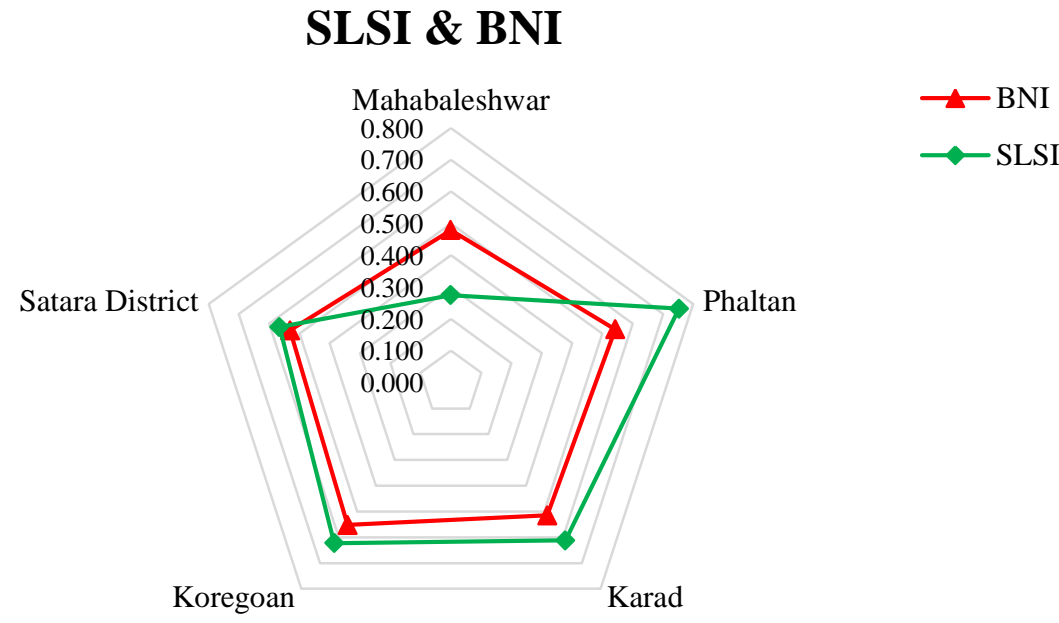

(c) 2021 EPRA ARER | www.eprajournals.com | Journal DOI URL: https://doi.org/10.36713/epra0813 


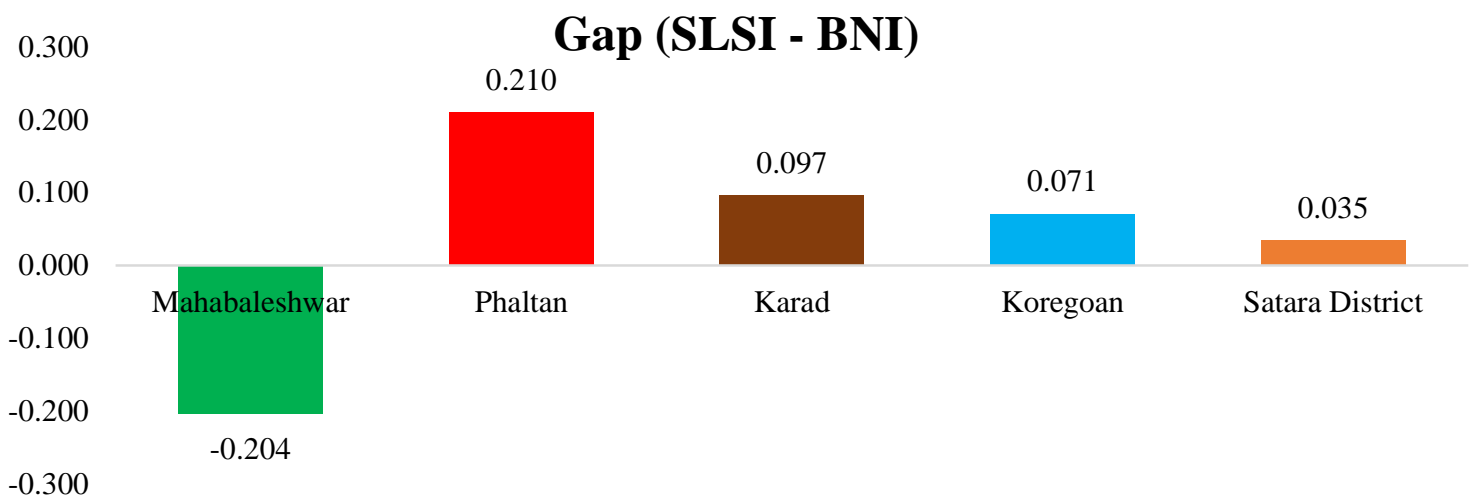

Table - 17 \& Fig. 09 illustrates the selected tehsil wise Bare Necessities Index (BNI) and Sustainable Livelihood Security Index (SLSI) in a rural area of Satara district. Considering BNI, the Bare Necessities Index of Koregaon has 0.552, which is highest and stood at rank $1^{\text {st }}$, also indicates Medium access of Bare Necessities to the people, followed by Phaltan, Karad and Mahabaleshwar i.e., 0.543, 0.515, and 0.479 respectively, it all have high access of bare necessities, excluding Mahabaleshwar, it has low access. Looking at the Satara district from selected tehsils, it has about 0.531 Other Facilities Index i.e., medium access to bare necessities in Satara district.

The composite index of three indices ESI, EEI, and SEI are called the Sustainable Livelihood Security Index (SLSI) which is one of the important policy tools for assessing agricultural sustainability of rural livelihood. The SLSI of selected tehsils has ranged between 0.275 to 0.753 . SLSI of Phaltan is 0.753, it has a high category, it has highest SLSI, followed by Koregaon has 0.623 , it has a high category. After that, Karad has 0.612 , which has also a high category and Mahabaleshwar has 0.275, which has the low category of SLSI.

The Bare Necessities Index of Koregaon has the highest and the Sustainable Livelihood Security Index of Phaltan is the highest. Mahabaleshwar shows SLSI and BNI gap, it has -0.204 which is the lowest, and Phaltan has calculated 0.210 which is the highest as compared to selected tehsils along with Satara district. followed by Koregaon and Karad it has 0.071 and 0.097 respectively which noted the highest of than Satara district. The gap between SLSI and BNI from the overall selected block i.e., Satara district is near to same, it has 0.035 during the study period.

\section{CONCLUDING REMARKS}

The paper focused its approach on to measure progress of the quality and equity of bare necessities accessible i.e., clean water, sanitation, shelter, electricity, cooking fuel, other facilities etc., is called the Bare Necessities Index. The BNI seems to have taken motivation from the design of the Multidimensional Poverty Index (MPI) which developed by Oxford Poverty and Human Development Initiative (OPHI). The main goal of development BNI to indicate government's willingness to implement a new and more relevant multi-dimensional lens, to objectively monitor policy implementation and evaluation of quality and equity of bare necessities in different areas.

SLSI is a composite index, it can work as a powerful tool to measure sustainable development and rural livelihood. As a policy tool, SLSI recognizes not only the districts requiring instant attention but also the specific thematic areas in which the efforts could be focused to achieve livelihood security. Thus, SLSI can work as an educational and policy tool encouraging an all-inclusive perspective among planners, administrators, and development workers. The important findings of selected tehsils-wise Bare Necessities Index (BNI) and Sustainable Livelihood Security Index (SLSI) in Satara district are:

1. Bare Necessities Index (BNI) of Satara district from selected tehsil was 0.531 , It ravel that medium level of the Bare necessities to the people of Satara district. Koregaon has highest BNI and rank first whereas Mahabaleshwar has lowest BNI, 0.479 which shows low level of access to BNI. Improvement in BNI is needed at all the selected tehsils of Satara district.

2. Sustainable Livelihood Security Index (SLSI) of Satara district from selected tehsil is 0.566, It indicates medium level of category of Sustainable Livelihood. Phaltan has highest SLSI, 0.753 however Koregaon and Karad has 0.623 and 0.612 respectively, The SLSI. Of Mahabaleshwar was 0.275 , which is very low as compared with other blocks, therefore Mahabaleshwar need to pay more attention from policy makers point

3. The relative difference between Sustainable Livelihood Security Index (SLSI) and Bare Necessities Index (BNI) of selected tehsil in Satara district was 0.035 
Moreover, Mahabaleshwar tehsil has lowest BNI and SLSI ranking, Koregoan tehsil was highest in BNI, but second highest in SLSI. Phaltan tahsil was highest in SLSI, but second highest in BNI as compared to selected tehsils in Satara district. According to estimated BNI and SLSI values of tehsils, Satara districts falls under medium performing category.

Acknowledgement: The authors are thankful to Indian Council of Social Science Research (ICSSR), New Delhi for providing the financial support to major research project titled as "An Analysis of Sustainable Livelihood Security in Western Maharashtra."

\section{REFERENCES}

1. Chambers, $R$ (1986), Sustainable Livelihoods: An Opportunity for the World Commission on Environment and Development, Brighton, England: Institute of Development Studies, University of Sussex.

2. Deshmukh M. S and Patil D. (2020) Economic Analysis of Agricultural Sustainability in Satara District of Maharashtra, Agricultural Situation in India, Vol - 47, Issue - 03, Directorate of Economics and Statistics Department of Agriculture, Cooperation \& Farmers Welfare Ministry of Agriculture \& Farmers Welfare Government of India 102A, F-Wing, Shastri Bhawan, New Delhi, 2020.

3. Frankenberger, T. (1996), Measuring household livelihood security: an approach for reducing absolute poverty, Food Forum, No. 34. Washington, DC, USA.

4. Government of India (2011), Census Report, Government of India

5. Government of India (2011), District Census Hand-Book/Satara District, 2011.

6. Government of India (2021), Economic Survey, Department of Finance and Statistics, Vol-1, New Delhi.

7. Nanaware D. and Kumbhar A. (2021), A Study of Sectorial Inequalities in Access of Bare Necessities of Satara District: An Analysis, EPRA_International Journal of Asian Economic Light, (IAEL), Vol-9, issue-2, June 2021.

8. Nanaware D. (2020), Gender Disparities in Various Social Groups in Solapur District in Maharashtra, India, EPRAInternational Journal of Socio-economic and Environmental Outlook (JSEEO), Vol-7, Issue-4, November 2020.

9. Swaminathan (1991), From Stockholm to Rio de Janeiro: The Road to Sustainable Agriculture. Monograph No. 4. M. S. Swaminathan Research Foundation, Chennai.

10. Sajjad, Nasreen and Ansari (2013), Assessing Spatiotemporal Variation in Agricultural Sustainability Using Sustainable Livelihood Security Index: Empirical Illustration from Vaishali District of Bihar, India, Agroecology and Sustainable Food Systems, Vol-38, Issue-1, November 2013.

11. Singh and Heiremath (2010), Sustainable livelihood security index in a developing country: A tool for development planning, ELSEVIER Ecological Indicators, Vol-10, Issue 2, March 2010. 